\title{
SOME ASPECTS OF INTERGOVERNMENTAL RELATIONS IN THE RUSSIAN FEDERATION
}

Intergovernmental relations are the relations between different levels of governments: federal government, state governments and local governments in financial (budget) sphere. The development of intergovernmental relations is very important for federalism, however federalism itself affects the relations.

Russian budget federalism of today is quite different from the previous one. In the soviet period of Russia, federalism was a state-centered system with the states (republics) continuing to administer the scores of local programs and the central government handling a specific few. Constitutional changes, historic developments, and social, political, and economic transformations of the nation - all of these have changed the meaning of the term «federalism» - «budget federalism». What started as an effort to create a perfect Union, in the 1990s evolved into a relatively integrated governmental system. Three levels of governments (federal government, state governments and local governments) are sovereign in their own assigned spheres of authority. However, only few would deny that current federal-state relationships are characterized far more by cooperation, coordination, and sharing the power than by separation and competition. National, state, and local governments are daily involved in mutual activities - constructing transports projects, etc. National government shares functions with state and local governments. «Federalism» has become synonymous with «intergovernmentalism», and «intergovernmentalism» has become synonymous with the «sharing functions». The pattern of intergovernmental cooperation has always been characteristic of Russian federalism (Russian budget federalism). Nevertheless, the model of distribution of functions of levels of Russian governments - and functions in financial sphere - has always been different.

The principal way the federal government makes policy in the federal system is through grants-in-aid to the states. As we have already said, intergovernmental relations involve interactions between the federal government and the states, between states, and between states and their localities. 
The Russian budget system has developed gradually over a number of years into what it is today. To understand the transformation of Russian budget federalism, it is necessary to look at the transformation that Russian society has experienced over the past twenty years. Historically, the new Russian Constitution of 1993 came into existence in response to recognized social, political, and economic needs - beginning with the Russian Federation. The Constitution of Russian Federation (1993) laid down the economic and juridical standards for the distribution of incomes and expenditure among the various budgets. Intergovernmental complexity has always been one of the most dynamic aspects of regulatory law, politics, and administration. Courts, legislatures, and agencies have found themselves involved in testing the boundaries of federalism; passage of legislation which intentionally builds in intergovernmental components. Budget laws were adapted to changing circumstances within the Constitution's parameters. Federal regulations have a direct impact on the states and localities.

The budget system is the principal link between federal, state and local governments in the financial federal system of Russia. If we view any budget system apart from the federal system of the country in which it exists, we may define it as the sum total of the budgets of all administrative-territorial regions and institutions of the country. In Russia the budget system covers all the budgets plus all the juridical standards determining the competence of central and local bodies in the compiling, approving and executing budgets. Every territory, region, autonomous region, area, district, city, town has its own budget, known as «local budget». Even though there are tens of thousands of budgets in the Russian Federation at present, they together comprise an integrated and harmonious budget system.

The division of revenues and expenditures of the federal budget, state budgets and local budgets is governed by the federal and state legislation. Federal legislation determines the organization of the budget system as a whole and the organization of intergovernmental relations. The main purpose of Russian legislature is to observe combining federal, state and local interests in financial affairs. In these circumstances there can be no or little opposition between central, state and local governments.

All budgets of Russian budget system have complex structure. For example, budgets as financial plans and funds of money include information about the level of revenue and necessary expenditures. The federal budget also includes the state insurance budget. Resources from the state insurance fund are used to aid purposes. This fund accumulates money for grants-in-aid system (financial aid system). The same insurance budgets are planned in state budgets. Local governments also hope for federal and state financial aid. Paralleling the national system, states also subsidize local governments on a massive scale. Thus, state and local governments depend heavily on the national governments for grants and subsidies in the Russian 
Federation. Grants are an important part of all budgets of budget system. Spending at a higher level of government becomes a revenue source at a lower level. About 30 percent of federal expenditures goes to states and localities in the forms of grants, funding everything from transport constructions to health programs. Although the amounts vary widely from state to state, approximately 20 percent of state revenue comes from the federal government. These federal grants can shape policies at all levels of government.

There are many reasons for providing financial aid to lower levels of governments.

The main reason is that states and localities really need money. In their attempts to raise revenue, state and local governments are limited by a number of factors. Most fundamentally, they are affected by the level of wealth. Unless they increase tax rates to unbearable levels, poor states simply cannot raise sufficient revenue to provide services comparable to those in more affluent areas. Moreover, when states do raise taxes, they risk causing an exodus of business, industry, and middle-class residents to the regions where taxes are lower. State and local governments also encounter constitutional limits of taxation. Federal tax policy has not been strongly limited by provisions of the Tax Code of Russian Federation. State and local governments have only those powers of taxation that federal laws (Tax Code) have granted them. The Tax Code prescribes what taxes state and local governments may impose, establishes the amount of taxation, specifies procedures of tax administration.

Another reason for providing financial aid to lower levels of governments is high level of state and local expenditures. There are several factors of growing state and local expenditures for the last ten years. States have greatly increased their share of funding for programs such education and welfare that previously were largely funded by federal governments. Urbanization and population growth have placed increasing demands on state and local governments for additional services. Wage increases, inflation have all put pressure on state and local governments to raise more sharing. State and local spending varies greatly among states and regions. Still, states and localities face many of the same financial problems because of the drop in federal aid and the elimination of revenue sharing. Many states and localities face serious problems of deteriorating infrastructures (roads, bridges, water systems etc.).

When tax revenue is insufficient to meet general operating costs or when state ant local governments wish to finance major capital programs such as highway or agriculture development, money must be borrowed. State and local borrowing is a standard procedure. It is regulated by the Budget Code of Russian Federation that places limits on borrowing. 
There are economic rationales that support the entire grants-in-aid system. It is easier to raise revenue at the national level than at the state and local levels. This is so because the federal tax structure is more flexible than that of the state and local governments. Federal revenues rise in direct proportion to overall economic growth. As a result, federal revenue expands greatly without any increase in tax rates. In contrast, state and local taxes are less flexible. A second economic rationale for grantsin-aid is spillover benefits. This means that the benefits obtained from a program administrated in one governmental area may extend into other governmental areas. Thus it seems fair that all who benefit should share the cost.

There are four reasons why federal money seemed, to state officials, so attractive. For one thing, the federal government is taking in more money than it is spending. The federal government, unlike the states, managed the currency and thus could print more money whenever it needed it. Federal aid often represents the largest source of revenue for the recipients.

Federal aid is known in the early years of Russian country. In the soviet period money was transferred to states. As a prototype of grant programs to come, the federal legislation established standards of cooperation for the state and national governments in the administration of joint projects. State and local governments were called upon to share the administration and financing parts of the program. Later the government adopted plans for federal-state cash support. As federal policymakers exerted greater and greater influence over state and local decision making and administration, the ardor of state and local officials for grants began to cool.

Grants are not the only kind of intergovernmental relations. Fiscal federalism - grants of money from the national government to the states and from the states to local governments - is at the center of intergovernmental relations. Federal government shares taxes with state and local government. It means that one level of government spends money raised at another level of government. Revenue sharing is an important experiment in federal-state-local finance. General revenue sharing program was not regulated for a long time. Nowadays it is regulated by the Budget Code. For example, it is proposed to return 70 percent of federal individual income tax revenue to the states (Article 56 of the Budget Code of the Russian Federation). State and local officials liked the program of revenue sharing because they felt that they could better decide how to spend money provided to them than federal officials who are geographically and emotionally distant from their problems.

In addition to general revenue sharing, other suggestions have been offered to reform the grant system. Grants are another source of revenue for state and local governments and they represent a significant contribution to state budgets. Grants-inaid mean payments made by voluntary appropriation from one level of government to another. Such grants are common from higher to local levels. One argument for 
increased federal involvement in traditional state and local activities has been that it provides a degree of national uniformity (in the form of minimal standards) in a system divided by interstate cooperation. Also, because of great differences in state wealth, spending for such programs as public assistance varies greatly from one part of the country to another. Federal aid can do more by transferring money from rich states to poor states. As a result, the federal grants-in-aid program has provided a politically acceptable way of providing needed money to state and local governments while keeping the formal structure of federalism.

There are three types of federal grants to states (state grants to localities):

1) block grants,

2) categorical grants - subsidies,

3) categorical grants - subventions.

Block grants - as opposed to other types of grants are used when the state and local governments do not or cannot provide a public service at a sufficiently high level without the help of the federal government. The result is that the money available for state and local government services enables authorities all over the country to provide services of roughly equal standard. Citizens living in poorer areas may have to accept a poorer environment, but they do not suffer appreciably in the quality of their schools, housing, road maintenance and other basic services. Thus, block grants represent a balance between national goals and the interests of states. Under a typical block grant program state and local agencies receive a larger amount of money that is awarded for some general purposes, such as transportation, for example.

Block grants are much broader in their scope. They allow a greater choice by the recipient. Block grants give states greater independence, than categorical grants. Block grants give states governments great discretion in how the money should be spent and generally is used for a wide range of purposes within a broad policy area such as education.

Block grants as a form of grants are given under a very complex formula that takes into consideration such factors as total population, state and local tax revenue, federal tax liabilities, and degree of urbanization.

Grants awarded for specific purposes are called categorical grants. There are two forms of categorical grants: subsidies and subventions. Subsidies are given for specific purposes and programs, such as education, transport, job training, highway safety, prevention of juvenile delinquency, agricultural extension, public assistance, employment security, educational assistance, hospital construction, etc. 
Subventions are the financial base of functions of federal governments delegated to state governments.

Federal aid which is connected with a specific category of services, welfare or highway construction, for example, is categorical aid. Categorical grants reached their present level of importance during the turbulent decade of 1990s. Frustrated by their inability to influence the behaviour of state and local agencies, national policymakers seized upon categorical aid as a means of ensuring compliance with national policy objectives. Categorical grants tend to be more popular with federal governments than with state and local officials. Categorical grants represent an attempt by national policymakers to take the money where the action is. Subsidies and subventions are mostly redistributed, and states governments have less discretion in how the money should be spent than in case of block grants. So the federal governments retains more control with this type of grant.

The dominance of categorical grants is a relatively new phenomenon. Categorical grants reached their present level of importance in 1995. Frustrated by their inability to influence the behaviour of state and local agencies, national policymakers seized upon categorical aid as a means of ensuring compliance with national policy objectives.

There are two major funding models by which grant money can be allocated.

In one case, money is distributed by formula (e.g. in accord with the percentage of the population below the official poverty line, level tax revenue) - block grants. Block grants are determined by a complex formula that has been changed from time to time.

In the other case, money is provided for specific projects and programs under special conditions. The conditions attached to the grants received are the most important federal restrictions on state action. Some conditions are specific for particular programs. Others are general, covering most or all grants. The second model is the largest category of on-budget expenditures. Over 70 percent of federal spending goes for these programs. Grant programs have been in use long enough to prove that they are avenues through which the national government has encroached upon the rightful role of states in the federal system. Federal grant programs made it possible for the redistribution of nationally collected resources to guarantee a minimum level of services for the nation. This was necessary because all states are not equally blessed with fiscal resources and all needs are not equally spread among the states.

The tendency at both national and state levels since 1990s has been to combine types of grants - block grants and categorical grants (subsidies and subventions). 
Although grants-in-aid are found in a wide variety of forms, the common characteristic of all forms is the central government's provision for aid for a particular service, without supplanting the responsibilities and powers of the recipient units of government which actually perform the service. Grants are usually made in the form of money, although the early grants were an exemption, as are some present grants of agricultural commodities. The federal grant program viewed as a whole may seem to be a hodgepodge, but it is the natural outgrowth of various goals and piecemeal development. The federal government has used the grant primarily to achieve some national goals, such as to get the farmer out of the mud or to prevent cancer, rather than merely to help state and local governments to finance existing programs. The great majority of all federal grants is for a relatively small number of programs. Grant program provides opportunities for states to add their own goals to grant programs. Federal grant program has given great impetus to the intergovernmentalization of the federal system. Specific programs are funded in only some of the areas in which problems exist. Nearly 70 percent of all grants are project grants.

In an urbanized society, it is no longer reasonable to view federalism only through the states. The nature of intergovernmental federalism must also take into consideration the localities. Many of grants for localities are for programs where the benefits are primarily local rather than national, such as local economic development and the construction and operation of local transportation systems. In contrast the states, local governments receive most of their federal aid in project grants.

Grants-in-aid from higher levels of government to lower ones have become a prominent part of Russian federal system. Federal grants allow to form national objectives, which are put into effect through the cooperation between federal officials and state and local governments. State-local relationships must be considered in the context of other federal relationships, the most important of which is the federallocal relationship. Local functions may be the subject for periodic inspection. National control of state and local government determines how local authorities are organized, what services they must provide, what other services they may provide if they choose to do so and how most of their services must be administrated.

Federal grants will continue to be an important factor in the federal-state and federal-local relations in the years ahead. Federal grants have become necessary to divert state attention from their own priorities and force them to remember that they are a part of the nation. 


\section{Streszczenie}

Przedmiotem rozważań w niniejszym opracowaniu są stosunki zachodzące pomiędzy organami publicznymi na różnych szczeblach władzy, tj. w realcjach pomiędzy rządami federalnym, państwowymi i lokalnymi. Każdy z ośrodków władzy jest niezależny w ramach przydzielonych obszarów działania, jednakże rząd federalny dzieli się zadaniami z rządami państwowymi i lokalnymi. W Federacji Rosyjskiej dwa ostatnie ośrodki uzyskują dotacje i subwencje od rządu federalnego. W dalszej części pracy szczegółowo analizowane są te dwie formy wsparcia finansowego. 